\title{
Article \\ Synthesis of Amorphous Conjugated Copolymers Based on Dithienosilole-Benzothiadiazole Dicarboxylic Imide with Tuned Optical Band Gaps and High Thermal Stability
}

\author{
Ary R. Murad ${ }^{1}$, Elham M. A. Dannoun ${ }^{2}{ }^{(}$, Shujahadeen B. Aziz ${ }^{3,4, *}{ }^{(0)}$, Ahmed Iraqi $\left.{ }^{5}{ }^{(}\right)$, Sozan N. Abdullah ${ }^{6}$, \\ Muaffaq M. Nofal ${ }^{7}$ and Ranjdar M. Abdullah ${ }^{3}$ \\ 1 Department of Pharmaceutical Chemistry, College of Medical and Applied Sciences, Charmo University, \\ Chamchamal, Sulaimani 46023, Iraq; ary.murad@charmouniversity.org \\ 2 General Science Department, Woman Campus, Prince Sultan University, P.O. Box 66833, \\ Riyadh 11586, Saudi Arabia; elhamdannoun1977@gmail.com \\ 3 Hameed Majid Advanced Polymeric Materials Research Lab., Department of Physics, College of Science, \\ University of Sulaimani, Qlyasan Street, Sulaimani 46001, Iraq; ranjdar.abdullah@univsul.edu.iq \\ 4 Department of Civil Engineering, College of Engineering, Komar University of Science and Technology, \\ Sulaimani 46001, Iraq \\ 5 Department of Chemistry, University of Sheffield, Sheffield S3 7HF, UK; a.iraqi@sheffield.ac.uk \\ 6 Department of Chemistry, College of Science, University of Sulaimani, Qlyasan Street, Kurdistan Regional \\ Government, Sulaimani 46001, Iraq; sozan.abdulla@univsul.edu.iq \\ 7 Department of Mathematics and General Sciences, Prince Sultan University, P.O. Box 66833, \\ Riyadh 11586, Saudi Arabia; muaffaqnofal@gmail.com \\ updates \\ * Correspondence: shujahadeenaziz@gmail.com or shujahadeen.aziz@univsul.edu.iq
}

Citation: Murad, A.R.; Dannoun E.M.A.; Aziz, S.B.; Iraqi, A.; Abdullah, S.N.; Nofal, M.M.; Abdullah, R.M Synthesis of Amorphous Conjugated Copolymers Based on

Dithienosilole-Benzothiadiazole Dicarboxylic Imide with Tuned Optical Band Gaps and High Thermal Stability. Appl. Sci. 2021, 11, 4866 https://doi.org/10.3390/app11114866

Academic Editor: Marta Sevilla

Received: 24 March 2021

Accepted: 11 May 2021

Published: 25 May 2021

Publisher's Note: MDPI stays neutral with regard to jurisdictional claims in published maps and institutional affiliations.

Copyright: (c) 2021 by the authors. Licensee MDPI, Basel, Switzerland. This article is an open access article distributed under the terms and conditions of the Creative Commons Attribution (CC BY) license (https:// creativecommons.org/licenses/by/ $4.0 /)$.

\begin{abstract}
Two alternating copolymers of dithienosilole (DTS) were designed and synthesized with small optical band gaps, flanked by thienyl units as electron-donor moieties and benzothiadiazole dicarboxylic imide (BTDI) as electron-acceptor moieties. The BTDI moieties were anchored to two different solubilizing side chains, namely 3,7-dimethyloctyl and n-octyl chains. An analysis of the effect of the electrochemical, optical, thermal, and structural characteristics of the resulting polymers along with their solubility and molecular weight is the subject of this paper. The Stille polymerization was used to synthesize PDTSDTBTDI-DMO and PDTSDTBTDI-8. The average molecular weight of PDTSDTBTDI-DMO and PDTSDTBTDI-8 is 14,600 and $5700 \mathrm{~g} \mathrm{~mol}^{-1}$, respectively. Both polymers have shown equivalent optical band gaps around $1.4 \mathrm{eV}$. The highest occupied molecular orbital (HOMO) levels of the polymers were comparable, around $-5.2 \mathrm{eV}$. The lowest unoccupied molecular orbital (LUMO) values were -3.56 and $-3.45 \mathrm{eV}$ for PDTSDTBTDI-DMO and PDTSDTBTDI-8, respectively. At decomposition temperatures above $350{ }^{\circ} \mathrm{C}$, both copolymers showed strong thermal stability. The studies of powder X-ray diffraction (XRD) have shown that they are amorphous in a solid-state.
\end{abstract}

Keywords: polymer synthesis; dithienosilole-based copolymers; stille polymerization; band gap study; cyclic voltammetry; UV-vis; XRD study; thermogravimetric analysis (TGA)

\section{Introduction}

In recent years, polymer solar cells (PSCs) using conjugated organic semiconductors have received enormous interest owing to their inherent benefits of low cost, light weight, manufacturing flexibility and large-scale devices through solution processing. Because of these benefits, PSCs dominate the global market for solar cells in such applications as wearable/portable electronics and building-integrated photovoltaic systems [1-3].

Significant developments in the design of solar cell polymers have come from the development of donor-acceptor (D-A) copolymers, which has led to highly efficient bulk heterojunction (BHJ) PSCs [4-8]. Low band-gap, energy levels and molecular structures of 
D-A polymers can be optimized via molecular engineering [9]. D-A copolymers contain electron-donor and electron-acceptor monomers [10], and in this class of polymers, the double-bond between the donor and acceptor units in the polymer backbone is increased, leading to the narrowing of the band gap of the corresponding polymers [11].

Over the years, researchers have developed high performance D-A copolymers for organic photovoltaic (OPV) applications. These polymers, such as fluorene, carbazole, anthracene, dibenzosilole (DBS), cyclopentadithiophene (CPDT), benzodithiophene (BDT), for use as electron-donating monomers and 2,1,3-benzothiadiazole (BT), 4,7-di-2thienyl-2,1,3-benzothiadiazole (DTBT), 4,7-di-2-thienyl-5,6-difluoro-2,1,3-benzothiadiazole (DTffBT), dithienyl-diketopyrrolopyrrole (DTDPP), thienothiophene (TT), thienopyrrole4,6-dione(TPD, for use as electron-accepting monomers.

Soluble conjugated polymers for applications in OPVs, the side chains attached to the polymer backbone, play an essential role in solution processing and miscibility with fullerene derivatives at the interface between regions [12]. They can also affect intermolecular interactions between different polymer backbones by changing torsional angles and $\pi-\pi$ stacking and lamellar packing [13].

Since several more sites along the backbone are available for chemical functionalization, the low band-gap D-A polymers are more flexible in structural modification. Electron-withdrawing functional groups (e.g., fluorine, a cyano group, ester, ketone or sulfonyl directly attached to the polymer backbone, or heteroatoms such as $\mathrm{Si}$ and Se in the backbone) can strongly influence the electronic properties of the resulting polymers, which include energy levels, band gap, charge mobility, and dipole moments $[10,13]$. The output of PSC devices reflects these factors well. Researchers have well developed the flexibility of substituent modification in fine-tuning their desired properties over the last decade.

Nowadays, on BHJ-type PSCs are the most effective. The optical-active layer of the $\mathrm{BHJ}$ consists of an interpenetrating system of electron-donor and electron-acceptor compounds. The power conversion efficiencies (PCEs) of this type of system has been documented at more than $17 \%$, which is a critical step towards industrial applications of OPVs. The fast production of new photoactive products, which entails the careful consideration of device optimization and interface constituents and the features of donors and acceptors (e.g., absorption, energy levels and band gaps), suggest a promising future for industrial applications of PSC systems. Consequently, the evolution of novel photovoltaic materials with a narrower optical band gap $\left(\mathrm{E}_{\mathrm{g}}\right)$, a deep highest occupied molecular orbital (HOMO) level and the lowest unoccupied molecular orbital (LUMO) level is critical for extra enhancement of the PCEs of the PSCs [14-16]. Attaining an optimal BHJ morphology that can balance exciton dissociation and charge transport is essential for attaining highperformance PSCs [17].

Dithienosilole (DTS) is a suitable donor unit for constructing low band gap conjugated polymers with an acceptor unit. DTS has a similar design as the CPDT donor unit except for having a bridging silicon atom instead of a carbon. In the DTS unit, the C-Si bond is longer than the carbon-carbon bond in the CPDT unit. Consequently, the steric impediment between the backbones of the conjugated polymer and solubilizing side chains is decreased. This results in greater $\pi-\pi$ stacking between polymer backbones as well as increased crystallinity and mobility of the charge carriers of the conjugated polymers containing the DTS unit [18].

The first copolymer, PDTSBT based on DTS, and BT, as a donor and acceptor units were investigated by Yang et al. In their system, hole mobility was observed to be three times greater than that in the PCPDTBT. Photovoltaic devices fabricated from PDTSBT: $\mathrm{PC}_{71} \mathrm{BM}$ gave a power conversion efficiency (PCE) of 5.1\% [19]. Bazan and co-workers developed a related copolymer, PDTSBT12, which has $n$-dodecyl chains on the silicon atom. The copolymer was synthesized via Stille-coupling polymerization and yielded a high molecular weight $\left(M_{\mathrm{n}}=34,000 \mathrm{~g} \mathrm{~mol}^{-1}\right)$. The PSC devices based on PDTSBT12:PC 71 BM exhibited a PCE of $5.9 \%$ [20]. 
Furthermore, Yang et al. reported the use of DTBT acceptor units in three copolymers: PDTS $\mathrm{H}_{\mathrm{H}} \mathrm{DTBT}$, PDTS $\mathrm{EH}_{\mathrm{H}} \mathrm{DTBT}$ and PDTS $_{12}$ DTBT. The first copolymer showed reduced solubility in typical organic solvents and could not be processed in $\mathrm{BHJ}$ solar cells. $\mathrm{PDTS}_{\mathrm{EH}} \mathrm{DTBT}$, blended with $\mathrm{PC}_{71} \mathrm{BM}$ in the $\mathrm{BHJ}$ photovoltaic cell, provided a PCE of $2.95 \%$; however, PDTS ${ }_{12}$ DTBT gave a PCE of $3.43 \%$. Consequently, the short-circuit current $\left(J_{\mathrm{sc}}\right)$ and fill factor $(F F)$ were improved [21]. This was likely because the $n$-dodecyl side chains have less steric hindrance than do the 2-ethylhexyl chains. These copolymers performed more effectively than their PCPDTDTBT analogues [22].

Tao et al. designed and synthesized a new type of copolymer, PDTSTPD, which used TPD as the acceptor unit [23]. The PDTSTPD that fabricated with $\mathrm{PC}_{71} \mathrm{BM}$ exhibited a very impressive PCE of $7.3 \%$. When a higher molecular weight polymer $\left(M_{n}=31,000 \mathrm{~g} \mathrm{~mol}^{-1}\right)$ was used, a higher PCE of 7.5\% was reported [24]. For the high molecular weight polymers, achieving a high PCE could be due to higher hole mobility, which lowered series resistance and raised the FF. In contrast with its PCPDTTPD analogue, PDTSTPD had a higher PCE $[25,26]$.

$\mathrm{Li}$ et al. synthesized a novel PDTSDTBTz copolymer with bithiazole (BTz) as an acceptor and two thiophene units between the BTz and DTS units. PDTSDTBTz displayed a PCE of $2.86 \%$, which was blended with $\mathrm{PC}_{71} \mathrm{BM}$ [27]. They developed two new copolymers, PDTSDTTTz- 3 and PDTSDTTTz- 4 with a more rigid and more coplanar geometry. Thiazolo [5,4-d]thiazole (TTz) was used as an acceptor unit. The locations of the solubilizing side chains on the thiophene units between DTS and TTz were altered. Increased backbone planarity and stronger intermolecular interactions facilitated the hole mobility of PDTSDTTTz-3 more than that of its PDTSDTBTz analogue. A PCE of 5.59\% was achieved from blending PDTSDTTTz-3 with $\mathrm{PC}_{71} \mathrm{BM}$, while the PCE for PDTSDTTTz-4-PC ${ }_{71} \mathrm{BM}$ improved to yield $5.88 \%$ with a considerable $F F$ of $71.6 \%$. This was due to the more planar structure of PDTSDTTTz-4, which had a higher hole mobility than its PDTSDTTTz-3 analogue [28].

The DTS was copolymerized with a naphtho(2,3-c)thiophene-4,9-dione (NTDO) acceptor to form a new copolymer, PDTSNTDO. A PCE of $5.21 \%$ was obtained from the blending of PDTSNTDO and PC $_{71}$ BM [29].

PDTSDTTAZ and PDTSTAZ were synthesized with and without thiophene spacers by the Stille polymerization between DTS and the benzotriazole (TAZ) acceptor unit. The steric hindrance of the polymer was reduced when two thiophene moieties were used between donor and acceptor units, which also provided a more planar polymer backbone. In contrast to the PDTSTAZ analogue, PDTSDTTAZ blended with $\mathrm{PC}_{71} \mathrm{BM}$ in a $\mathrm{BHJ}$ photovoltaic cell demonstrated a PCE of $1.64 \%$ vs $3.80 \%$, respectively [30]. Earlier reports indicated that small band gap conductive polymers are crucial for optoelectronics and organic solar cell devices. The results of the present study emphasize that copolymerization can be a novel approach to designing and synthesizing conjugated copolymers with lowor small-energy band gaps.

\section{Experimental Section}

2.1. Materials

Compounds 1-11 were synthesized in accordance with updated procedures [31-41]. Compounds 12 and 13 were synthesized according to published procedures [42-45]. Compounds 14-16 were prepared according to modified procedures [46-48]. The 4,7di(5-bromo-thien-2-yl)-2,1,3-benzothiadiazole-5,6-N-(3,7-dimethyloctyl)dicarboxylic imide (M1) and 4,7-di(5-bromo-thien-2-yl)-2,1,3-benzothiadiazole-5,6-N-octyl-dicarboxylic imide (M2) were prepared according to published procedures [42-45]. Finally, 4,4-dioctyl-5,5'bis(trimethylstannyl)dithieno[3,2-b:2', $3^{\prime}$-d] silole (M3) was synthesized according to published procedures [49]. The procedures used to prepare monomers M1, M2, and M3 are available in the Supplementary Materials. All chemicals and solvents were purchased from Alfa Aesar and Sigma-Aldrich. They were used without purification. The majority of the 
reactions took place under an argon atmosphere. For reactions, anhydrous solvents from Grubbs solvent purification system at the University of Sheffield were used.

\subsection{Measurements}

Both ${ }^{1}$ Hand ${ }^{13} \mathrm{C}$ nuclear magnetic resonance (NMR) spectra were recorded with a Bruker Advanced AV 3HD (400 MHz) spectrometer and a Bruker AV 3HD (500 MHz) spectrometer at room temperature using chloroform- $d\left(\mathrm{CDCl}_{3}\right)$, acetone- $\mathrm{d}_{6}\left(\mathrm{CD}_{3} \mathrm{COCD}_{3}\right)$ or dimethyl sulfoxide- $\mathrm{d}_{6}\left(\mathrm{CD}_{3} \mathrm{SOCD}_{3}\right)$. With the Bruker $\mathrm{AV} 3 \mathrm{HD}(500 \mathrm{MHz})$ spectrometer, the ${ }^{1} \mathrm{H}$ NMR spectra for the polymers were recorded in 1,1,2,2-tetrachloroethane- $\mathrm{d}_{2}\left(\mathrm{C}_{2} \mathrm{D}_{2} \mathrm{Cl}_{4}\right)$ at $100{ }^{\circ} \mathrm{C}$. The chemical shifts were recorded in parts per million (ppm). The coupling constants $(J)$ were measured in Hertz $(\mathrm{Hz})$. Both ${ }^{1} \mathrm{H}$ and ${ }^{13} \mathrm{C}$ NMR spectra were investigated using Bruker Top Spin 3.2 software. The PerkinElmer 2400 Series II CHNS/O Elemental Analyser or Vario MICRO Cube CHN/S Elemental Analyser were used to perform the elemental analysis (CHN). Schöniger oxygen flask combustion technique was conducted to analyze anions such as $\mathrm{Br}$, I and S. The mass spectra of the monomers were registered on an Agilent 7200 (Q-TOF GC-MS) accurate mass spectrometer. As a carrier gas, helium was used at the rate of $1.2 \mathrm{~mL} \mathrm{~min}^{-1}$ with an injection volume of $1.0 \mu \mathrm{L}$, and a measured sample concentration of $5 \mathrm{mg} \mathrm{mL}^{-1}$ in $\mathrm{CHCl}_{3}$ solvent. The temperature was programmed to vary from 60 to $320{ }^{\circ} \mathrm{C}$ at a rate of $10^{\circ} \mathrm{C} \mathrm{min}{ }^{-1}$. The electron ionization method (EI) provided mass spectra for the monomers. Gel permeation chromatography (GPC) tests were conducted with the Viscotek GPC Max and water 410 instruments with a detector of a differential refractive index, two Polymer Labs PLgel $5 \mu$ Mixed C columns $(7.5 \times 300 \mathrm{~mm})$, and a guard of $7.5 \times 50 \mathrm{~mm}$. Using high-pressure liquid chromatography (HPLC)-grade $\mathrm{CHCl}_{3}$, molecular weights for the polymers were measured by preparing polymer solutions of $2.5 \mathrm{mg} \mathrm{mL}$. The columns were thermostated using $\mathrm{CHCl}_{3}$ at $40^{\circ} \mathrm{C}$. UV-vis absorption spectra were studied at room temperature with a SPECORD S600 $\mathrm{UV} /$ visible spectrophotometer. Polymer absorbance was carried out in $\mathrm{CHCl}_{3}$ solution using quartz cuvettes (optical path length $10 \mathrm{~mm}$ ), including the $\mathrm{CHCl}_{3}$ solution. The blank quartz cuvette was first taken as a background reference. The polymers were coated with $\mathrm{CHCl}_{3}$ solutions $\left(1 \mathrm{mg} \mathrm{mL}^{-1}\right)$ on quartz substrates, and the blank quartz substrate was used as a reference. The PerkinElmer (Pyris 1) thermogravimetric analyser was used to perform the thermogravimetric analysis (TGA) measurements. As a sample holder, platinum pans were used, and the samples were weighted to be around $3 \mathrm{mg}$. Cyclic voltammograms were carried out by a Princeton Applied Research 263A Potentiostat/Galvanostat. Based on a Pt disk working electrode, a typical three-electrode system was used. A silver wire reference electrode $\left(\mathrm{Ag} / \mathrm{Ag}^{+}\right)$was placed in $0.01 \mathrm{M}$ of $\mathrm{AgNO}_{3}$ solution in acetonitrile and mounted in the electrolyte solution. During all measurements at room temperature, a $\mathrm{Pt}$ wire counter electrode was purged with an argon atmosphere. Tetrabutylammonium perchlorate in acetonitrile $\left(0.1 \mathrm{M}, \mathrm{Bu}_{4} \mathrm{NClO}_{4} / \mathrm{CH}_{3} \mathrm{CN}\right)$ was employed as the electrolyte.

For the casting of the polymer thin films, the polymer solutions were measured in $\mathrm{CH}_{3} \mathrm{Cl}\left(1 \mathrm{mg} \mathrm{mL}^{-1}\right)$ onto the $\mathrm{Pt}$ disk and dried under nitrogen before measurements were taken. As a reference redox system, ferrocene $\left(\mathrm{Fc} / \mathrm{Fc}^{+}\right)$was used. The Bruker D8 ADVANCE X-ray powder diffractometer was used to measure powder X-ray diffraction (XRD). Infrared absorption spectra were determined by the ATR PerkinElmer Rx/FT-IR and Nicolet Model 205 FT-IR spectrometers.

\subsection{Polymers Synthesis}

Synthesis of poly[4,4-dioctyl-2,6-dithieno[3,2-b:2',3'-d]silole-alt-5,5-(4',7'-bis(2-thienyl)$2^{\prime}, \mathbf{1}^{\prime}, 3^{\prime}$-benzothiadiazole-5,6-N-(3,7-dimethyloctyl)-dicarboxylic imide) (PDTSDTBTDIDMO): (89.0 mg, $0.134 \mathrm{mmol})$ of M1, (100.0 mg, $0.134 \mathrm{mmol})$ of M3, $(2.2 \mathrm{mg}, 0.0097 \mathrm{mmol})$ of $\mathrm{Pd}(\mathrm{OAc})_{2}$ and $(6.1 \mathrm{mg}, 0.020 \mathrm{mmol})$ of $\mathrm{P}(\mathrm{o} \text {-tol })_{3}$ were mixed and degassed under argon. Dry toluene $(5 \mathrm{~mL})$ was added and the system was further degassed and heated for $72 \mathrm{~h}$ at $110{ }^{\circ} \mathrm{C}$. The reaction mixture was cooled to room temperature and dissolved in $300 \mathrm{~mL}$ $\mathrm{CHCl}_{3}$. Ammonium hydroxide solution $(50 \mathrm{~mL})$ was then added to the mixture stirred 
overnight. The organic phase was subsequently separated and washed with deionized water. Later, the organic phase was reduced to about $50 \mathrm{~mL}$ and put into $300 \mathrm{~mL}$ methanol and stirred overnight. Then, the mixture filtered and the polymer purified using Soxhlet extraction with $300 \mathrm{~mL}$ each of methanol, acetone, hexane, toluene and chloroform. The toluene and chloroform fractions were concentrated to about $50 \mathrm{~mL}$ and then put into $300 \mathrm{~mL}$ of methanol. After the mixture was stirred overnight, the pure polymer was obtained by filtration to yield PDTSDTBTDI-DMO as blue powders, $(42.0 \mathrm{mg}, 0.045 \mathrm{mmol}$, $33.90 \%$ yield $)$ of toluene fraction, $(72.0 \mathrm{mg}, 0.077 \mathrm{mmol}, 58.12 \%$ yield $)$ of chloroform fraction with total yield 92.02\%. GPC: Toluene fraction, $M_{\mathrm{n}}=6200 \mathrm{~g} \mathrm{~mol}^{-1}, M_{\mathrm{w}}=20,600 \mathrm{~g} \mathrm{~mol}^{-1}$, PDI = 3.2 and Dp = 7; chloroform fraction, $M_{\mathrm{n}}=14,600 \mathrm{~g} \mathrm{~mol}^{-1}, M_{\mathrm{w}}=79,900 \mathrm{~g} \mathrm{~mol}^{-1}$, $\mathrm{PDI}=5.4$ and $\mathrm{Dp}=16 .{ }^{1} \mathrm{H} \mathrm{NMR}$ (toluene fraction) $\left(\mathrm{C}_{2} \mathrm{D}_{2} \mathrm{Cl}_{4}, \delta\right): 8.16-8.01(\mathrm{bm}, 2 \mathrm{H})$, 7.54-7.17 (bm, 4H), 3.87-3.65 (bm, 2H), 1.81-1.67 (bm, 1H), 1.60-1.50 (bm, 3H), 1.48-1.07 (bm, 33H), 1.05-0.94 (bm, 6H), 0.89-0.78 (bm, 10H). FT-IR $\left(\mathrm{cm}^{-1}\right)$ : 3129, 3062, 2955, 2923, 2848, 1753, 1696, 1546, 1510, 1425, 1400, 1350, 1168, 1104, 1068, 1011, 897, 836, 793, 761, 743, 688. Elemental analysis (\%) calculated for $\mathrm{C}_{50} \mathrm{H}_{61} \mathrm{~N}_{3} \mathrm{O}_{2} \mathrm{~S}_{5} \mathrm{Si}: \mathrm{C}, 64.96 ; \mathrm{H}, 6.65 ; \mathrm{N}, 4.55 ; \mathrm{S}$, 17.34. Found: C, 63.29; H, 6.49; N, 4.74; S, 17.10 .

Synthesis of poly[4,4-dioctyl-2,6-dithieno[3,2-b:2', $3^{\prime}$-d] silole-alt-5,5-(4',7'-bis(2-thienyl)$2^{\prime}, \mathbf{1}^{\prime}, \mathbf{3}^{\prime}$-benzothiadiazole-5,6-N-octyl-dicarboxylic imide) (PDTSDTBTDI-8): PDTSDTBTDI8 was synthesized following the same synthesizing procedure for PDTSDTBTDI-DMO: $(91.0 \mathrm{mg}, 0.143 \mathrm{mmol})$ of M2 and $(107.0 \mathrm{mg}, 0.143 \mathrm{mmol})$ of M3 were copolymerized using $(2.3 \mathrm{mg}, 0.01 \mathrm{mmol})$ of $\mathrm{Pd}(\mathrm{OAc})_{2}$ and $(6.5 \mathrm{mg}, 0.021 \mathrm{mmol})$ of $\mathrm{P}(\mathrm{o} \text {-tol })_{3}$ in $5 \mathrm{~mL}$ anhydrous toluene at $110{ }^{\circ} \mathrm{C}$ for $72 \mathrm{~h}$. (73.0 mg, $0.081 \mathrm{mmol}, 57.00 \%$ yield) of PDTSDTBTDI- 8 was obtained as blue powders. GPC: toluene fraction, $M_{\mathrm{n}}=5700 \mathrm{~g} \mathrm{~mol}^{-1}, M_{\mathrm{w}}=14,000 \mathrm{~g} \mathrm{~mol}^{-1}$, $\mathrm{PDI}=2.4$ and $\mathrm{Dp}=6 .{ }^{1} \mathrm{H} \mathrm{NMR}$ (toluene fraction) $\left(\mathrm{C}_{2} \mathrm{D}_{2} \mathrm{Cl}_{4}, \delta\right): 8.19-8.01(\mathrm{bm}, 2 \mathrm{H}), 7.55-7.20$ (bm, 4H), 3.87-3.66 (bm, 2H), 1.841 .64 (bm, 2H), 1.61-1.07 (bm, 34H), 1.06-0.92 (bm, 3H), 0.89-0.78 (bm, 10H). FT-IR (cm $\left.{ }^{-1}\right): 3129,3062,2951,2919,2851,1749,1689,1549,1514$, $1425,1403,1350,1161,1007,893,836,793,747,686$. Elemental analysis (\%) calculated for $\mathrm{C}_{48} \mathrm{H}_{57} \mathrm{~N}_{3} \mathrm{O}_{2} \mathrm{~S}_{5} \mathrm{Si}: \mathrm{C}, 64.32 ; \mathrm{H}, 6.41 ; \mathrm{N}, 4.69 ; \mathrm{S}, 17.88$. Found: C, 63.09; H, 6.19; N, 5.11; $\mathrm{S}, 17.63$.

\section{Results and Discussion}

\subsection{Polymer Synthesis}

In our work, we synthesized two alternating copolymers comprising benzothiadiazole dicarboxylic imide (BTDI) with varying substituents flanked by two thienyl repeat units as electron-accepting moieties and DTS as electron donor moieties. The preparation of polymers PDTSDTBTDI-DMO and PDTSDTBTDI-8 is presented in Scheme 1. Both polymerizations were performed for $72 \mathrm{~h}$, and dark blue precipitates were obtained, which were then dissolved in chloroform with the addition of an $\mathrm{NH}_{4} \mathrm{OH}$ solution. The mixture was stirred overnight to eliminate the residue of the Pd metal catalyst which yielded $\mathrm{Pd}\left(\mathrm{NH}_{3}\right)_{4}(\mathrm{OH})_{2}$ soluble complexes. The polymers were achieved by precipitation from methanol accompanied by filtration. Finally, the polymers were purified through Soxhlet extraction using methanol, acetone, hexane, toluene, and chloroform. The methanol, acetone, and hexane fractions separated small molecules, oligomers, and some impurities. Subsequently, the toluene and chloroform fractions were collected then re-precipitated in methanol accompanied by filtration to obtain the purified polymers. ${ }^{1} \mathrm{HNMR}, \mathrm{FT}-\mathrm{IR}$ and elemental analyses were carried out to confirm the structures of the PDTSDTBTDIDMO and PDTSDTBTDI-8. The ${ }^{1} \mathrm{HNMR}$ spectra for the polymers are available in the Supplementary Materials (see Figures S4 and S5). 


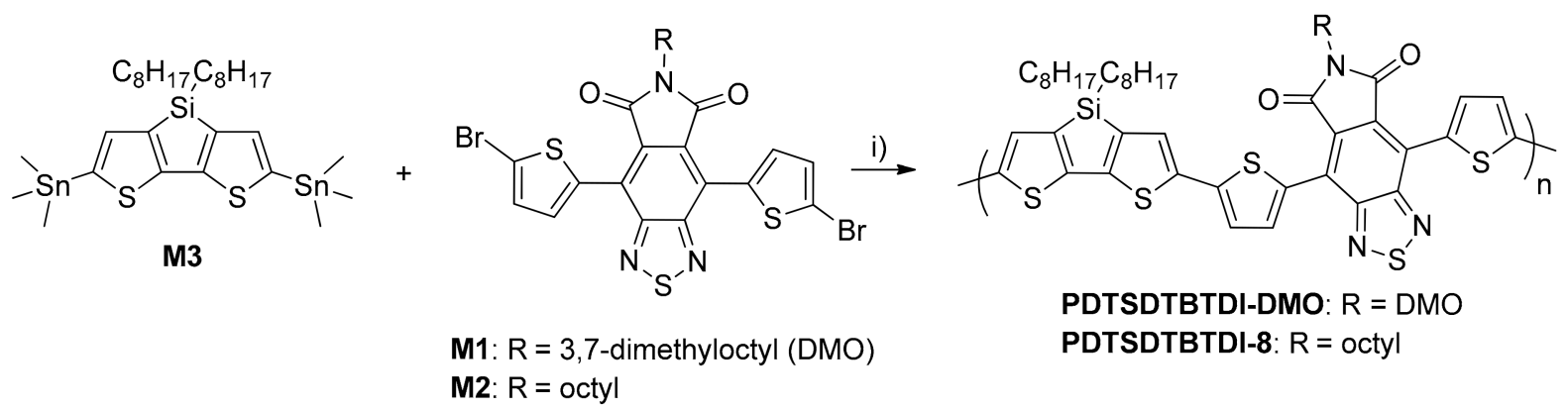

Scheme 1. The synthesis of PDTSDTBTDI-DMO and PDTSDTBTDI-8 via the Stille polymerization.

Reagents and conditions: (i) $\mathrm{Pd}(\mathrm{OAc})_{2}, \mathrm{P}(\mathrm{o} \text {-tol })_{3}$, toluene, $110^{\circ} \mathrm{C}, 72 \mathrm{~h}$.

\subsection{Molecular Weights and Yield of the Polymers}

Polymer molecular weights were measured via gel permeation chromatography (GPC) in $\mathrm{CHCl}_{3}$ solution at $40^{\circ} \mathrm{C}$ relative to polystyrene standards (Table 1). Altering the 3,7dimethyloctyl chains in PDTSDTBTDI-DMO to $n$-octyl chains in PDTSDTBTDI-8 on the BTDI units resulted in slightly lower average molecular weight $\left(M_{n}\right)$ values for the toluene fractions of the polymers. Furthermore, PDTSDTBTDI-DMO yielded a chloroform fraction of a higher $M_{n}$ value. The results indicated that the PDTSDTBTDI-8 had lower solubility since the DTS and BTDI units have $n$-octyl chains. As a result, a low molecular weight polymer was obtained. PDTSDTBTDI-DMO yielded a perfect amount and had a considerably higher molecular weight than PDTSDTBTDI-8. This could be owing to the higher solubility of PDTSDTBTDI-DMO.

Table 1. The percentage of production, weight and number average molecular weights with polydispersity indexes of PDTSDTBTDI-DMO and PDTSDTBTDI-8.

\begin{tabular}{|c|c|c|c|c|c|c|c|}
\hline \multirow[b]{2}{*}{ Polymer } & \multirow[b]{2}{*}{$\%$ Yield } & \multicolumn{3}{|c|}{ Toluene Fraction } & \multicolumn{3}{|c|}{ Chloroform Fraction } \\
\hline & & $\begin{array}{c}M_{\mathrm{n}} \\
\left(\mathrm{g} \mathrm{mol}^{-1}\right)\end{array}$ & $\begin{array}{c}M_{\mathrm{w}} \\
\left(\mathrm{g} \mathrm{mol}^{-1}\right)\end{array}$ & PDI & $\begin{array}{c}M_{\mathrm{n}} \\
\left(\mathrm{g} \mathrm{mol}^{-1}\right)\end{array}$ & $\begin{array}{c}M_{\mathrm{w}} \\
\left(\mathrm{g} \mathrm{mol}^{-1}\right)\end{array}$ & PDI \\
\hline PDTSDTBTDI-DMO & 92 & 6200 & 20,600 & 3.2 & 14,600 & 79,900 & 5.4 \\
\hline PDTSDTBTDI-8 & 57 & 5700 & 14,000 & 2.4 & & & \\
\hline
\end{tabular}

\subsection{Optical Properties of the Polymers}

Figure 1a,b shows the normalized Ultraviolet-visible (UV-vis) absorption spectra of the PDTSDTBTDI-DMO and PDTSDTBTDI-8 polymers in (a) chloroform solutions and (b) on thin films, respectively. Table 2 summarizes the optical properties of the polymers. The absorption maxima of PDTSDTBTDI-DMO were found to be red-shifted compared to PDTSDTBTDI-8 in both solutions and thin films. This might have arisen because the former polymer's molecular weight was higher than that of the latter polymer. In the thin films, the absorption peaks of both PDTSDTBTDI-DMO and PDTSDTBTDI-8 displayed a bathochromic shift relative to their absorption in the solutions with maximal absorption at 689 and $670 \mathrm{~nm}$. This could be due to the more aggregated and planar structures in the solid-state form. The band gap $\left(\mathrm{E}_{\mathrm{g}}\right)$ values of the polymers were measured from the absorption onsets in the thin films. The $\mathrm{E}_{\mathrm{g}}$ was found to be comparable at about $1.4 \mathrm{eV}$ for both polymers. The altering alkyl chains on BTDI units from 3,7-dimethyloctyl into $n$-octyl chains had an insignificant effect on the resulting polymers' band gap. The $\mathrm{E}_{\mathrm{g}}$ of both polymers were found to be slightly lower than PDTSBT $(1.45 \mathrm{eV})$ and lower than the PDTS $\mathrm{EH}_{\mathrm{BTBT}}$ and PDTS $_{12}$ DTBT counterparts (1.53 and $1.51 \mathrm{eV}$, respectively). This could be because the BTDI unit had a stronger electron-accepting property than the BT unit did. Both polymers also showed a remarkably lower $E_{g}$ than those of their PDTSDTBTz, PDTSDTTTz-3, PDTSDTTTz-4 and PDTSTPD counterparts, which were found to be 1.85 , 
$1.81,1.76$ and $1.73 \mathrm{eV}$, respectively. Compared to the $\mathrm{E}_{\mathrm{g}}$ of PDTSDTTAZ, PDTSTAZ and PDTSNTDO (1.81, 1.78 and $1.65 \mathrm{eV}$, respectively), both polymers had a significantly lower $\mathrm{E}_{\mathrm{g}}$. The significant lowering of band gaps is thought to be a result of adopting a $2 \mathrm{D}$ (thin film) structure since the band gap is known to be low in symmetric 2D soft matter systems [50]. As a result, this new type of polymer adopted more planar structures with a greater intrachain charge transfer alongside the polymer backbone. The absorption coefficient $(\varepsilon)$ of PDTSDTBTDI-DMO was much higher than that of PDTSDTBTDI-8. This may be attributed to the greater molecular weight and red-shifted absorption maxima of the PDTSDTBTDI-DMO polymer.
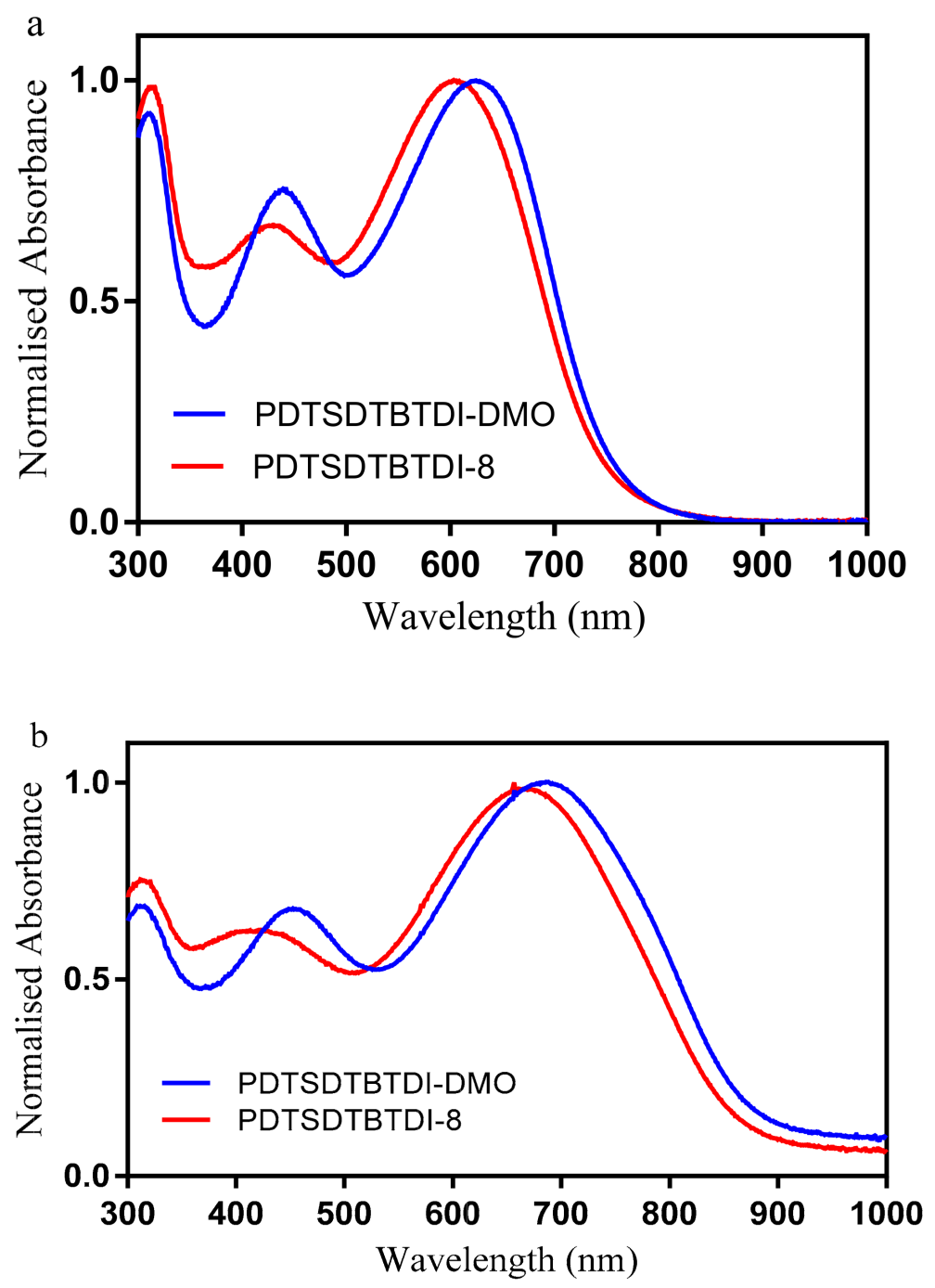

Figure 1. Normalized UV-vis absorption spectra of PDTSDTBTDI-DMO and PDTSDTBTDI-8 in (a) chloroform solutions; and (b) on thin films.

Table 2. The UV-vis data and optical band gaps of the polymers.

\begin{tabular}{|c|c|c|c|c|c|}
\hline \multirow{2}{*}{ Polymer } & \multirow{2}{*}{$\left(\mathrm{M}^{-1} \mathrm{~cm}^{-1}\right)$} & \multirow{2}{*}{$\begin{array}{c}\text { Solution } \\
\lambda_{\max }(\mathrm{nm})\end{array}$} & \multicolumn{3}{|c|}{ Film } \\
\hline & & & $\lambda_{\max }(\mathrm{nm})$ & $\lambda_{\text {onset }}(\mathrm{nm})$ & $E_{g}(e V)$ \\
\hline PDTSDTBTDI-DMO & 32,300 & 627 & 689 & 873 & 1.42 \\
\hline PDTSDTBTDI-8 & 23,400 & 613 & 670 & 863 & 1.43 \\
\hline
\end{tabular}




\subsection{Electrochemical Properties of the Polymers}

To investigate the electrochemical properties of the polymers, cyclic voltammetry was used. Figure 2 shows the cyclic voltammograms of PDTSDTBTDI-DMO and PDTSDTBTDI8 taken at $100 \mathrm{mV} / \mathrm{s}$ on a Pt electrode in $\mathrm{Bu}_{4} \mathrm{NClO}_{4} / \mathrm{CH}_{3} \mathrm{CN}$. The polymers' LUMO and $\mathrm{HOMO}$ values were determined from the onsets of reduction and oxidation potentials, respectively. The calculated values are summarized in Table 3. The onsets of cyclic voltammograms were determined on drop-cast polymer films on the platinum electrode as the working electrode of the reference electrode $\mathrm{Bu}_{4} \mathrm{NClO}_{4} / \mathrm{CH}_{3} \mathrm{CN}(0.1 \mathrm{M})$ versus $\mathrm{Ag} / \mathrm{Ag}^{+}$. The HOMO values for both PDTSDTBTDI-DMO and PDTSDTBTDI-8 polymers are equivalent although the former polymer's LUMO energy level is lower than that of the latter. These findings show that adding different side chains onto BTDI units had an insignificant effect on the polymers' degree of HOMO. However, around $0.1 \mathrm{eV}$, the LUMO levels of the polymers showed an influence. The donor unit's nature dominated the HOMO energy level, and the DTS donor unit was the same for both polymers. The polymers had a slightly deeper HOMO level than did PDTSDTBTz, which was found to be $-5.18 \mathrm{eV}$. The HOMO energy levels of both polymers were observed to be more profound in comparison to those found for PDTSBT, PDTS $\mathrm{EH}_{\mathrm{H}}$ DTBT, PDTS ${ }_{12}$ DTBT and PDTSDTTTz-4 analogues $(-5.05,-4.99,-5.02$, and $-5.04 \mathrm{eV}$, respectively). However, the LUMO energy levels for both polymers were lower than those observed for PDTSBT, PDTS $\mathrm{EH}_{\mathrm{DTBT}}$, PDTS $_{12}$ DTBT and PDTSDTTTz-4 analogues $-3.27,-3.17,-3.19$ and $-3.41 \mathrm{eV}$, respectively. In addition to that, the two polymers' LUMO levels were also found to be significantly lower than the PDTSTAZ and PDTSDTTAZ values, where -2.76 and $-2.81 \mathrm{eV}$ were found, respectively. This could be attributed to the BTDI unit's having a stronger electronaccepting ability than the benzothiadiazole, dithienylbenzothiadiazole, thiazolothiazole, triazole and dithienyltriazole units. Conversely, compared to their PDTSTPD counterpart, the two polymers showed shallower HOMO and LUMO energy levels.

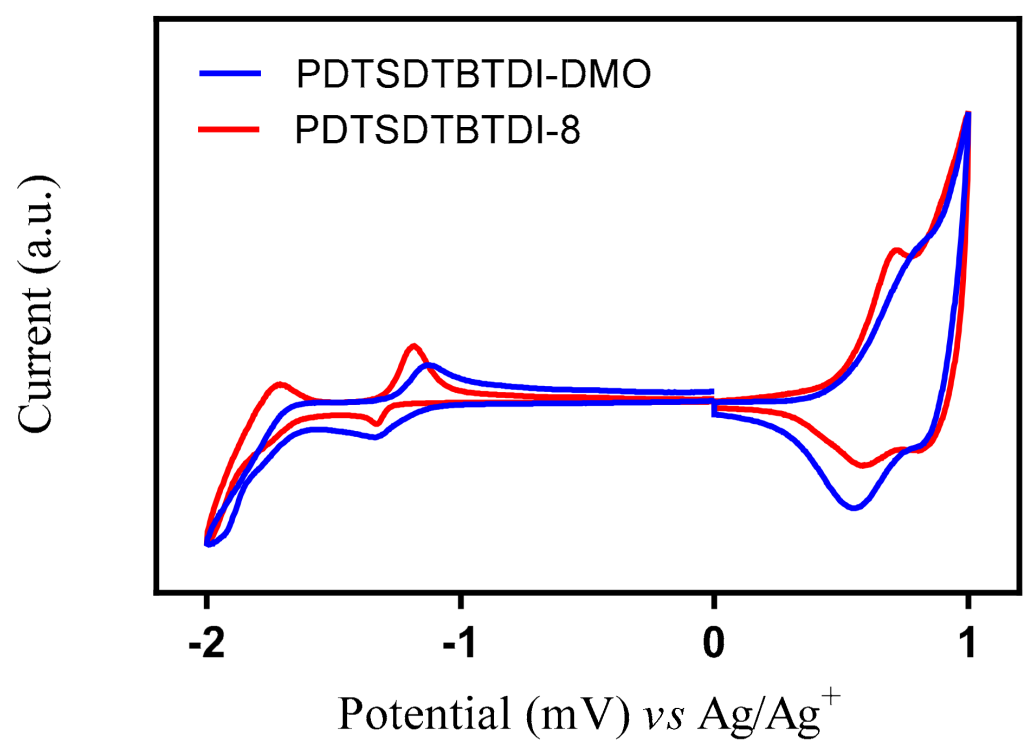

Figure 2. Cyclic voltammograms of PDTSDTBTDI-DMO and PDTSDTBTDI-8 on Pt electrode in $\mathrm{Bu} 4 \mathrm{NClO}_{4} / \mathrm{CH}_{3} \mathrm{CN}$.

Table 3. Electrochemical and thermal properties of the polymers.

\begin{tabular}{ccccccc}
\hline Polymer & $\boldsymbol{T}_{\mathbf{d}}\left({ }^{\circ} \mathbf{C}\right)$ & $\mathbf{E}_{\mathbf{o x}}{ }^{\mathbf{0}}(\mathrm{V})$ & HOMO $(\mathrm{eV})$ & $\mathrm{E}_{\text {red }}{ }^{\mathbf{0}}(\mathrm{V})$ & LUMO $(\mathrm{eV})$ & $\mathrm{E}_{\mathrm{g}(\mathrm{elec})}(\mathrm{eV})$ \\
\hline PDTSDTBTDI-DMO & 357 & 0.50 & -5.21 & 1.15 & -3.56 & 1.65 \\
PDTSDTBTDI-8 & 394 & 0.52 & -5.23 & 1.26 & -3.45 & 1.78 \\
\hline
\end{tabular}




\subsection{Thermal Properties of the Polymers}

Figure 3 shows the thermal properties of the polymers using thermogravimetric analysis (TGA). The thermal parameters of the polymers are listed in Table 3. The decomposition temperatures were $357^{\circ} \mathrm{C}$, and $394^{\circ} \mathrm{C}$ for the PDTSDTBTDI-DMO and PDTSDTBTDI-8 polymers, respectively. The TGA results show that the polymers' thermal stability was greatly influenced by the substituents' existence on the BTDI moieties. The polymers have thermal stability windows that are well within the range of those used for solar cells and could be stable for such use. In previous studies, TGA was used to evaluate the thermal properties of D-A conjugated polymers for PSC applications [51-56].

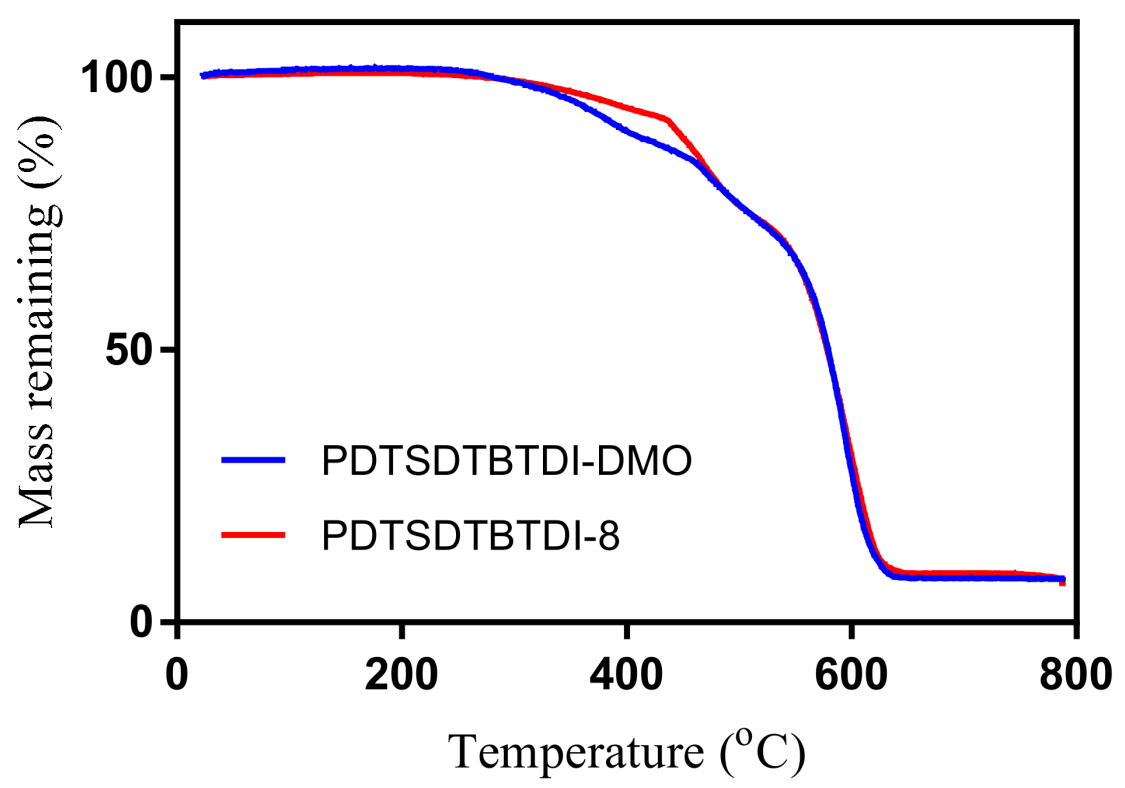

Figure 3. TGA of PDTSDTBTDI-DMO and PDTSDTBTDI-8.

PDTSDTBTDI-DMO and PDTSDTBTDI-8 were found to have slightly higher decomposition temperatures than those observed for PDTSDTTTz-4 and PDTSNTDO $\left(317^{\circ} \mathrm{C}\right.$ and $321^{\circ} \mathrm{C}$, respectively). PDTSDTBTDI-8 was found to have better thermal stability compared to PDTSDTBTz and PDTSTAZ ( 368 and $388^{\circ} \mathrm{C}$, respectively).

On the other hand, PDTSDTBTDI-DMO proved to be less stable than the polymers mentioned above. However, it is essential to mention that both polymers exhibited less thermal stability than PDTSDTTAZ with $T_{\mathrm{d}}$ at $415{ }^{\circ} \mathrm{C}$. The difference in the polymers thermal stabilities could be attributed to various side chains on the DTS units and different acceptor units.

\subsection{Powder X-ray Diffraction of the Polymers}

Powder X-ray diffraction (XRD) was carried out to investigate the structural properties of PDTSDTBTDI-DMO and PDTSDTBTDI-8 (Figure 4). The XRD spectra of PDTSDTBTDIDMO and PDTSDTBTDI-8 showed that the diffraction peaks exhibited at 24.6 and $24.9^{\circ}$ followed the $\pi-\pi$ stacking distance of 3.61 and $3.57 \AA$, respectively, and both polymers exhibited an amorphous structure. The powder XRD of the polymers was identical to that of PDTSDTBTz. However, as stated in the literature, PDTSBT showed features of crystallinity. 


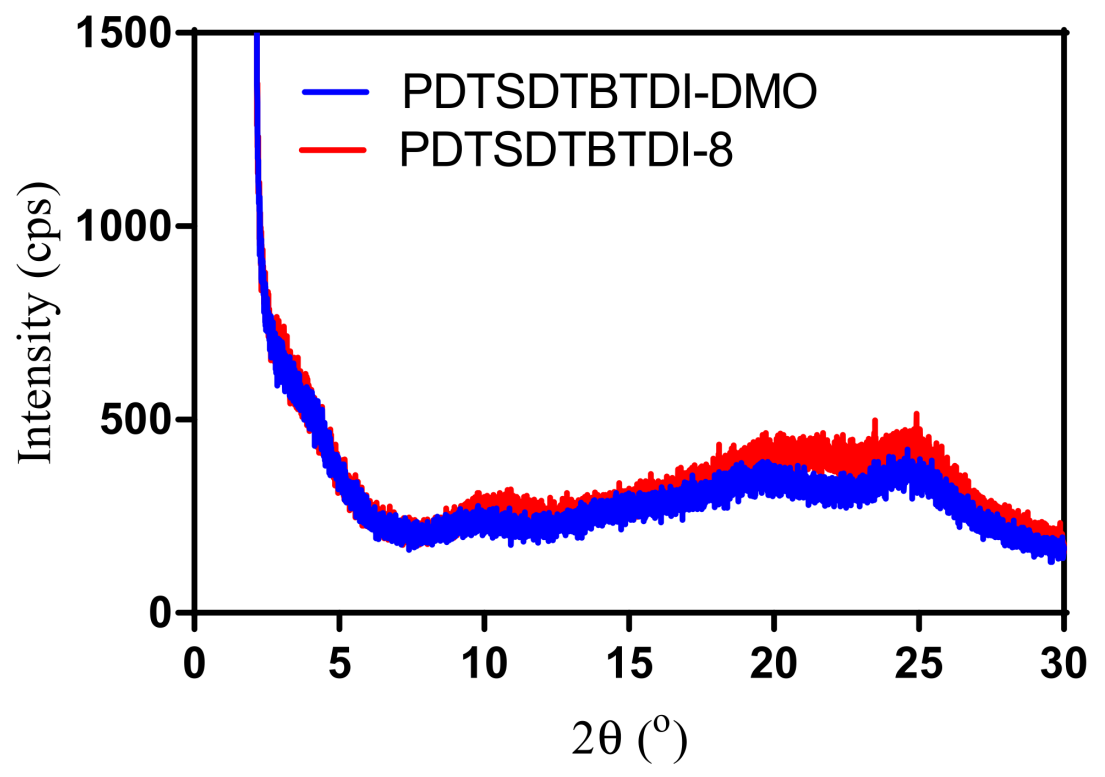

Figure 4. Powder XRD of PDTSDTBTDI-DMO and PDTSDTBTDI-8.

\section{Conclusions}

To summarise, Stille polymerization was used to synthesise two new low bandgap conjugated copolymers, such as dithienosilole (DTS), flanked by thienyl moieties as donor units and by benzothiadiazole dicarboxylic imide (BTDI) as acceptor units. To prepare PDTSDTBTDI-DMO and PDTSDTBTDI-8 (yielding 92\% and 57\%, respectively) distannylated DTS monomer (M3) was copolymerised with dibrominated BTDI monomers (M1 and M2). The BTDI units were attached to two different side chains, $n$-octyl and 3,7dimethyloctyl, to study the impact of these substituents on the resulting polymers' optical, electrochemical, thermal, and structural properties, as well as their solubility and molecular weight. Anchoring 3,7-dimethyloctyl chains in PDTSDTBTDI-DMO and n-octyl chains in PDTSDTBTDI-8 to the BTDI units negatively affected solubility and molecular weight. The soxhlet extraction process was conducted in the separation of PDTSDTBTDI-8, and its toluene fraction showed a low $M_{n}$ value $\left(5700 \mathrm{~g} \mathrm{~mol}^{-1}\right)$ because of its limited solubility. Soxhlet extraction of PDTSDTBTDI-DMO gave two fractions; a toluene fraction with a slightly higher $M_{\mathrm{n}}$ value than for PDTSDTBTDI-8 and a chloroform fraction with a $M_{\mathrm{n}}$ value more than twice as high. The absorption maxima of PDTSDTBTDI-8 in the solution and the thin-film were blue-shifted compared to PDTSDTBTDI-DMO absorption. For both polymers, the absorption spectra showed bathochromic shift absorption maxima in the thinfilms in contrast to their absorption in the solution. It was observed that both polymers had similar optical band gaps at approximately $1.4 \mathrm{eV}$. The HOMO levels of the polymers were found to be similar, and the LUMO levels of the PDTSDTBTDI-DMO and PDTSDTBTDI8 were found to be -3.56 and $-3.45 \mathrm{eV}$, respectively. The attaching of different alkyl chains to the BTDI units slightly affected the band gaps and HOMO levels, whereas LUMO energy levels were influenced by approximately $0.1 \mathrm{eV}$. PDTSDTBTDI-DMO and PDTSDTBTDI-8 showed good thermal stability with decomposition temperatures at 357 and $394{ }^{\circ} \mathrm{C}$, respectively. By changing substituents on the imide functionality of BTDI units, the polymers' thermal properties were significantly affected. The powder XRD studies of the polymers exhibited diffraction peaks at around $24^{\circ}$ in proportion to the $\pi-\pi$ stacking distance of about 3.6 $\AA$. The two polymers were found to be amorphous in nature.

Supplementary Materials: Supplementary Materials are available online at https://www.mdpi. com/article/10.3390/app11114866/s1. 
Author Contributions: Conceptualization, A.R.M., S.B.A. and A.I.; Formal analysis, A.R.M.; Funding acquisition, E.M.A.D.; Methodology, A.R.M. and S.N.A.; Project administration, S.B.A. and A.I.; Supervision, A.I.; Validation, E.M.A.D., S.B.A., A.I., S.N.A., M.M.N.; R.M.A.; Visualization, M.M.N.; Writing—original draft, A.R.M.; Writing—review \& editing, E.M.A.D., S.B.A., A.I., S.N.A., M.M.N., R.M.A. All authors have read and agreed to the published version of the manuscript.

Funding: This research received no external funding.

Institutional Review Board Statement: Not applicable.

Informed Consent Statement: Not applicable.

Data Availability Statement: Exclude this statement because the study did not report any data.

Acknowledgments: We would like to acknowledge all support for this work by the University of Sulaimani, Prince Sultan University, Charmo University and Komar University of Science and Technology. The authors would like to acknowledge the support of Prince Sultan University for paying the Article Processing Charges (APC) of this publication and for their financial support.

Conflicts of Interest: The authors declare no conflict of interest.

\section{References}

1. Lee, C.; Lee, S.; Kim, G.; Lee, W.; Kim, B.J. Recent advances, design guidelines, and prospects of all-polymer solar cells. Chem. Rev. 2019, 119, 8028-8086. [CrossRef] [PubMed]

2. Murad, A.; Iraqi, A.; Aziz, S.; Abdullah, S.; Brza, M. Conducting polymers foroptoelectronic devices andorganic solar cells: A review. Polymers 2020, 12, 2627. [CrossRef] [PubMed]

3. Huang, F.; Bo, Z.; Geng, Y.; Wang, X.; Wang, L.; Ma, Y.; Hou, J.; Hu, W.; Pei, J.; Dong, H.; et al. Study on optoelectronic polymers: An overview and outlook. Acta Polym. Sin. 2019, 50, 988-1046.

4. Huo, L.; Hou, J.; Zhang, S.; Chen, H.-Y.; Yang, Y. A polybenzo[1,2-b:4,5-b']dithiophene Derivative with Deep HOMO Level and its application in high-performance polymer solar cells. Angew. Chem. Int. Ed. 2010, 49, 1500-1503. [CrossRef]

5. Price, S.C.; Stuart, A.C.; Yang, L.; Zhou, H.; You, W. Fluorine Substituted conjugated polymer of medium band gap yields 7\% efficiency in polymer-fullerene solar cells. J. Am. Chem. Soc. 2011, 133, 4625-4631. [CrossRef] [PubMed]

6. Liang, Y.; Yu, L. A new class of semiconducting polymers for bulk heterojunction solar cells with exceptionally high performance. Acc. Chem. Res. 2010, 43, 1227-1236. [CrossRef] [PubMed]

7. Cabanetos, C.; El Labban, A.; Bartelt, J.A.; Douglas, J.D.; Mateker, W.R.; Fréchet, J.M.J.; McGehee, M.D.; Beaujuge, P.M. Linear side chains in Benzo[1,2-b:4,5-b']dithiophene Thieno[3,4-c]pyrrole-4,6-dione polymers direct self-assembly and solar cell performance. J. Am. Chem. Soc. 2013, 135, 4656-4659. [CrossRef]

8. $\quad$ Liang, Y.; Xu, Z.; Xia, J.; Tsai, S.T.; Wu, Y.; Li, G.; Ray, C.; Yu, L. For the bright future-bulk heterojunction polymer solar cells with power conversion efficiency of 7.4\%. Adv. Mater. 2010, 22, E135-E138. [CrossRef]

9. Zhou, H.; Yang, L.; You, W. Rational Design of high performance conjugated polymers for organic solar cells. Macromolecules 2012, 45, 607-632. [CrossRef]

10. Lu, L.; Zheng, T.; Wu, Q.; Schneider, A.M.; Zhao, D.; Yu, L. Recent advances in bulk heterojunction polymer solar cells. Chem. Rev. 2015, 115, 12666-12731. [CrossRef]

11. Zhang, Q.T.; Tour, J.M. Low optical band gap polythiophenes by an alternating donor/acceptor repeat unit strategy. J. Am. Chem. Soc. 1997, 119, 5065-5066. [CrossRef]

12. Mei, J.; Bao, Z. Side chain engineering in solution-processable conjugated polymers. Chem. Mater. 2014, 26, 604-615. [CrossRef]

13. Jhuo, H.; Yeh, P.; Liao, S.; Li, Y.; Cheng, Y.; Chen, S. Review on the recent progress in low band gap conjugated polymers for bulk hetero-junction polymer solar cells. J. Chin. Chem. Soc. 2014, 61, 115-126. [CrossRef]

14. Zheng, B.; Huo, L.; Li, Y. Benzodithiophenedione-based polymers: Recentadvances in organic photovoltaics. NPG Asia Mater. 2020, 12, 3. [CrossRef]

15. Liu, X.; Zhang, C.; Pang, S.; Li, N.; Brabec, C.J.; Duan, C.; Huang, F.; Cao, Y. Ternary all-polymer solar cells with 8.5\% power conversion efficiency and excellent thermal stability. Front. Chem. 2020, 8, 302. [CrossRef]

16. El Karkri, A.; El Malki, Z.; Bouachrine, M.; Serein-Spirau, F.; Sotiropoulos, J. Characterization and simulation study of organicsolar cells based on donor-acceptor (D- $\pi-\mathrm{A})$ molecular materials. RSC Adv. 2020, 10, 18816-18823. [CrossRef]

17. Weng, K.; Ye, L.; Zhu, L.; Xu, J.; Zhou, J.; Feng, X.; Lu, G.; Tan, S.; Liu, F.; Sun, Y. Optimised active layer morphology toward efficient and polymer batch insensitive organic solar cells. Nat. Commun. 2020, 11, 2855. [CrossRef]

18. Chen, H.Y.; Hou, J.; Hayden, A.E.; Yang, H.; Houk, K.; Yang, Y. Silicon atom substitution enhances interchain packing in a thiophene-based polymer system. Adv. Mater. 2010, 22, 371-375. [CrossRef]

19. Hou, J.; Chen, H.-Y.; Zhang, S.; Li, G.; Yang, Y. Synthesis, Characterization, and photovoltaic properties of a low band gap polymer based on silole-containing polythiophenes and 2,1,3-benzothiadiazole. J. Am. Chem. Soc. 2008, 130, 16144-16145. [CrossRef]

20. Coffin, R.C.; Peet, J.; Rogers, J.; Bazan, G.C. Streamlined microwave-assisted preparation of narrow-bandgap conjugated polymers for high-performance bulk heterojunction solar cells. Nat. Chem. 2009, 1, 657-661. [CrossRef] 
21. Huo, L.; Chen, H.-Y.; Hou, J.; Chen, T.L.; Yang, Y. Low band gap dithieno[3,2-b:2', $\left.3^{\prime}-d\right]$ silole-containing polymers, synthesis, characterisation and photovoltaic application. Chem. Commun. 2009, 37, 5570-5572. [CrossRef] [PubMed]

22. Moulé, A.J.; Tsami, A.; Bünnagel, T.W.; Forster, M.; Kronenberg, N.M.; Scharber, M.; Koppe, M.; Morana, M.; Brabec, C.J.; Meerholz, K. Two novel cyclopentadithiophene-based alternating copolymers as potential donor components for high-efficiency bulk-heterojunction-type solar cells. Chem. Mater. 2008, 20, 4045-4050. [CrossRef]

23. Chu, T.-Y.; Lu, J.; Beaupré, S.; Zhang, Y.; Pouliot, J.-R.; Wakim, S.; Zhou, J.; Leclerc, M.; Li, Z.; Ding, J. Bulk heterojunction solar cells using thieno[3,4-c]pyrrole-4,6-dione and dithieno[3,2-b:2', $3^{\prime}$-d] silole copolymer with a power conversion efficiency of $7.3 \%$. J. Am. Chem. Soc. 2011, 133, 4250-4253. [CrossRef] [PubMed]

24. Chu, T.Y.; Lu, J.; Beaupré, S.; Zhang, Y.; Pouliot, J.R.; Zhou, J.; Najari, A.; Leclerc, M.; Tao, Y. Effects of the molecular weight and the side-chain length on the photovoltaic performance of dithienosilole/thienopyrrolodione copolymers. Adv. Funct. Mater. 2012, 22, 2345-2351. [CrossRef]

25. Guo, X.; Xin, H.; Kim, F.S.; Liyanage, A.D.; Jenekhe, S.A.; Watson, M.D. Thieno[3,4-c]pyrrole-4,6-dione-based donor-acceptor conjugated polymers for solar cells. Macromolecules 2010, 44, 269-277. [CrossRef]

26. Li, Z.; Tsang, S.W.; Du, X.; Scoles, L.; Robertson, G.; Zhang, Y.; Toll, F.; Tao, Y.; Lu, J.; Ding, J. alternating copolymers of cyclopenta $\left[2,1-b ; 3,4-b^{\prime}\right]$ dithiophene and Thieno $[3,4-c]$ pyrrole-4, 6-dione for high-performance polymer solar cells. Adv. Funct. Mater. 2011, 21, 3331-3336. [CrossRef]

27. Zhang, M.; Fan, H.; Guo, X.; He, Y.; Zhang, Z.; Min, J.; Zhang, J.; Zhao, G.; Zhan, X.; Li, Y. Synthesis and photovoltaic properties of bithiazole-based donor-acceptor copolymers. Macromolecules 2010, 43, 5706-5712. [CrossRef]

28. Zhang, Z.-G.; Min, J.; Zhang, S.; Zhang, J.; Zhang, M.; Li, Y. Alkyl chain engineering on a dithieno [3, 2-b: 2', 3'-d] silole-altdithienylthiazolo $[5,4-\mathrm{d}]$ thiazole copolymer toward high performance bulk heterojunction solar cells. Chem. Commun. 2011, 47, 9474-9476. [CrossRef]

29. Cui, C.; Fan, X.; Zhang, M.; Zhang, J.; Min, J.; Li, Y. AD-A copolymer of dithienosilole and a new acceptor unit of naphtho [2, 3-c] thiophene-4, 9-dione for efficient polymer solar cells. Chem. Commun. 2011, 47, 11345-11347. [CrossRef]

30. Min, J.; Zhang, Z.-G.; Zhang, S.; Zhang, M.; Zhang, J.; Li, Y. Synthesis and photovoltaic properties of D-A copolymers based on dithienosilole and benzotriazole. Macromolecules 2011, 44, 7632-7638. [CrossRef]

31. Ponomarenko, S.A.; Muzafarov, A.M.; Borshchev, O.V.; Vodopyanov, E.A.; Demchenko, N.V.; Myakushev, V.D. Synthesis of bithiophenesilane dendrimer of the first generation. Russ. Chem. Bull. 2005, 54, 684-690. [CrossRef]

32. Wen, L.; Rasmussen, S.C. Synthesis and structural characterisation of 2,5-dihalo-3,4-dinitrothiophenes. J. Chem. Crystallogr. 2007, 37, 387-398. [CrossRef]

33. Schwiderski, R.L.; Rasmussen, S.C. Synthesis and characterization of thieno[3,4- $b]$ pyrazine-based terthienyls: Tunable precursors for low band gap conjugated materials. J. Org. Chem. 2013, 78, 5453-5462. [CrossRef] [PubMed]

34. Hailu, H.; Gebru, B.A.; Admassie, S.; Mammo, W.; Raju, V.J.; Chebude, Y. Variable denticity of a multidentate terthiophene derivative towards Ni (II) and Zn (II)-structural studies. Bull. Chem. Soc. Ethiop. 2011, 25, 221-231. [CrossRef]

35. Delgado, M.R.; Hernandez, V.; Navarrete, J.L.; Tanaka, S.; Yamashita, Y. Combined spectroscopic and theoretical study of narrow band gap heterocyclic co-oligomers containing alternating aromatic donor and o-quinoid acceptor units. J. Phys. Chem. 2004, 108, 2516-2526. [CrossRef]

36. Wang, L.; Cai, D.; Zheng, Q.; Tang, C.; Chen, S.; Yin, Z. Low band gap polymers incorporating a dicarboxylic imide-derived acceptor moiety for efficient polymer solar cells. ACS Macro Lett. 2013, 2, 605-608. [CrossRef]

37. Nielsen, C.B.; Ashraf, R.S.; Treat, N.D.; Schroeder, B.C.; Donaghey, J.E.; White, A.J.; Stingelin, N.; McCulloch, I. 2,1,3Benzothiadiazole-5,6-Dicarboxylic Imide-A versatile building block for additive- and annealing-free processing of organic solar cells with efficiencies exceeding 8\%. Adv. Mater. 2015, 27, 948-953. [CrossRef]

38. Lan, L.; Chen, Z.; Li, Y.; Ying, L.; Huang, F.; Cao, Y. Donor-acceptor conjugated polymers based on cyclic imide substituted quinoxaline or dibenzo[a,c]phenazine for polymer solar cells. Polym. Chem. 2015, 43, 7558-7569. [CrossRef]

39. Matsueda, Y.; Xu, S.; Negishi, E. A novel highly enantio- and diastereoselective synthesis of vitamin E side-chain. Tetrahedron Lett. 2015, 56, 3346-3348. [CrossRef]

40. Thomson, A.; O'Connor, S.; Knuckley, B.; Causey, C.P. Design, synthesis, and in vitro evaluation of an activity-based protein profiling (ABPP) probe targeting agmatine deiminases. Bioorg. Med. Chem. 2014, 22, 4602-4608. [CrossRef]

41. Yue, W.; Zhao, Y.; Shao, S.; Tian, H.; Xie, Z.; Geng, Y.; Wang, F. Novel NIR-absorbing conjugated polymers for efficient polymer solar cells: Effect of alkyl chain length on device performance. J. Mater. Chem. 2009, 19, 2199-2206. [CrossRef]

42. Murad, A.R.; Iraqi, A.; Aziz, S.B.; Abdullah, S.N.; Abdulwahid, R.T.; Hussen, S.A. Optical, electrochemical, thermal, and structural properties of synthesised fluorene/dibenzosilole-benzothiadiazole dicarboxylic imide alternating organic copolymers for photovoltaic applications. Coatings 2020, 10, 1147. [CrossRef]

43. Murad, A.R.; Iraqi, A.; Aziz, S.B.; Hi, H.; Abdullah, S.N.; Brza, M.A.; Abdulwahid, R.T. Influence of fluorine substitution on the optical, thermal, electrochemical and structural properties of carbazole-benzothiadiazole dicarboxylic imide alternate copolymers. Polymers 2020, 12, 2910. [CrossRef] [PubMed]

44. Murad, A.R.; Iraqi, A.; Aziz, S.B.; Almeataq, M.S.; Abdullah, S.N.; Brza, M.A. Characteristics of low band gap copolymers containing anthracene-benzothiadiazole dicarboxylic imide: Synthesis, optical, electrochemical, thermal and structural studies. Polymers 2021, 13, 62 . 
45. Murad, A.R.; Iraqi, A.; Aziz, S.B.; Abdullah, S.N.; Brza, M.A.; Saeed, S.R.; Abdulwahid, R.T. Fabrication of alternating copolymers based on cyclopentadithiophene-benzothiadiazole dicarboxylic imide with reduced optical band gap: Synthesis, optical, electrochemical, thermal, and structural properties. Polymers 2021, 13, 63.

46. Khor, E.; Ng, S.C.; Li, H.C.; Chai, S. Selective functionalization of 2,2'-bithiophenes. Heterocycles 1991, 32, 1805-1812. [CrossRef]

47. Letizia, J.A.; Salata, M.R.; Tribout, C.M.; Facchetti, A.; Ratner, M.A.; Marks, T.J. N-Channel polymers by design: Optimising the interplay of solubilising substituents, crystal packing, and field-effect transistor characteristics in polymeric bithiophene-imide semiconductors. J. Am. Chem. Soc. 2008, 130, 9679-9694. [CrossRef]

48. Beaujuge, P.M.; Tsao, H.N.; Hansen, M.R.; Amb, C.M.; Risko, C.; Subbiah, J.; Choudhury, K.R.; Mavrinskiy, A.; Pisula, W.; Brédas, J.-L. Synthetic principles directing charge transport in low-band-gap dithienosilole-benzothiadiazole copolymers. J. Am. Chem. Soc. 2012, 134, 8944-8957. [CrossRef]

49. Medlej, H.; Awada, H.; Abbas, M.; Wantz, G.; Bousquet, A.; Grelet, E.; Hariri, K.; Hamieh, T.; Hiorns, R.C.; Dagron-Lartigau, C. Effect of spacer insertion in a commonly used dithienosilole/benzothiadiazole-based low band gap copolymer for polymer solar cells. Eur. Polym. J. 2013, 49, 4176-4188. [CrossRef]

50. Eslami, H.; Gharibi, A.; Müller-Plathe, F. Mechanisms of nucleation and solid-solid-phase transitions in Triblock Janus Assemblies. J. Chem. Theory Comput. 2021, 17, 3. [CrossRef]

51. Liu, C.; Cai, W.; Guan, X.; Duan, C.; Xue, Q.; Ying, L.; Huang, F.; Cao, Y. Synthesis of donor-acceptor copolymers based on anthracene derivatives for polymer solar cells. Polym. Chem. 2013, 4, 3949-3958. [CrossRef]

52. Cartwright, L.; Taylor, L.J.; Yi, H.; Iraqi, A.; Zhang, Y.; Scarratt, N.W.; Wang, T.; Lidzey, D.G. Triisopropylsilylacetylenefunctionalised anthracene-alt-benzothiadiazole copolymers for application in bulk heterojunction solar cells. RSC Adv. 2015, 5, 101607-101615. [CrossRef]

53. Cartwright, L.; Neal, T.J.; Rutland, N.J.; Iraqi, A. Anthracene-thieno[3,4-c]pyrrole-4,6-dione based donor-acceptor conjugated copolymers for applications in optoelectronic devices. Polym. Adv. Technol. 2016, 27, 525-531. [CrossRef]

54. Cartwright, L.; Iraqi, A.; Zhang, Y.; Wang, T.; Lidzey, D.G. Impact of fluorine substitution upon the photovoltaic properties of benzothiadiazole-fluorene alternate copolymers. RSC Adv. 2015, 5, 46386-46394. [CrossRef]

55. Cartwright, L.; Yi, H.; Iraqi, A. Effect of fluorination pattern and extent on the properties of PCDTBT derivatives. New J. Chem. 2016, 40, 1655-1662. [CrossRef]

56. Murad, R.; Iraqi, A.; Aziz, S.B.; Abdullah, S.N.; Abdulwahid, R.T. Synthesis, optical, thermal and structural characteristics of novel thermocleavable polymers based on phthalate esters. Polymers 2020, 12, 2791. [CrossRef] 